\title{
Isolation from a shea cake digester of a tannin- degrading Streptococcus gallolyticus strain that decarboxylates protocatechuic and hydroxycinnamic acids, and emendation of the species
}

\footnotetext{
${ }^{1}$ Laboratoire de Microbiologie IRD, Unité de Biotechnologie Microbienne Post-Récolte, IFR-BAIM, Universités de Provence et de la Méditerranée, ESIL case 925, 163 Avenue de Luminy, 13288 Marseille Cedex 9, France

2 Microbial Research and Discovery Unit, School of Biomolecular and Biomedical Sciences, Faculty of Science, Griffith University, Brisbane, Queensland 4111, Australia

${ }^{3}$ Laboratoire de Biotechnologie et de Technologie Alimentaire, Université de Ouagadougou, Burkina Faso
}

\author{
Mohamed Chamkha, ${ }^{1}$ Bharat K. C. Patel, ${ }^{2}$ Alfred Traore, ${ }^{3}$ \\ Jean-Louis Garcia' ${ }^{1}$ and Marc Labat ${ }^{1}$ \\ Author for correspondence: Marc Labat. Tel: +3349182 8575. Fax: +33 491828570 . \\ e-mail: labat@esil.univ-mrs.fr
}

\begin{abstract}
A facultatively anaerobic, mesophilic, non-motile, non-sporulating bacterium, designated strain B7, was isolated from an anaerobic digester fed with shea cake rich in tannins and aromatic compounds, after enrichment on tannic acid. The coccoid cells (less than $\mathbf{2} \mu \mathrm{m}$ in diameter) occurred in pairs or short chains and stained Gram-positive. Strain B7 fermented a wide range of carbohydrates (cellobiose, fructose, galactose, glucose, lactose, maltose, mannitol, melibiose, raffinose and trehalose), grew optimally at pH 7.0 and had a $\mathrm{G}+\mathrm{C}$ content of 40.4 $\pm 0.3 \mathrm{~mol} \%$. Strain B7 was closely related to Streptococcus gallolyticus ACM $3611^{\top}$, a member of the Streptococcus bovis rRNA cluster, with a sequence similarity of $98 \%$ and a DNA hybridization value of $86 \mathrm{~mol} \%$. Isolate B7 hydrolysed tannic acid and decarboxylated gallic acid to pyrogallol, traits also observed in S. gallolyticus ACM 3611'. In addition, both strains decarboxylated protocatechuic acid to catechol, p-coumaric acid to 4-vinylphenol, caffeic acid to 4-vinylcatechol and ferulic acid to 4-vinylguaiacol. An unsubstituted parahydroxyl group on the benzene ring was required for decarboxylation. Glucose addition markedly increased the conversion rate. As these traits were not described previously, emendation of the description of the species Streptococcus gallolyticus is proposed.
\end{abstract}

Keywords: Streptococcus gallolyticus, tannin hydrolysis, aromatic compounds, decarboxylation, emendation

\section{INTRODUCTION}

Tannins are a group of highly polar phenolic compounds found in plant extracts. These oligomeric compounds, with molecular weights of 500 $3000 \mathrm{~g} \mathrm{~mol}^{-1}$, form insoluble complexes with proteins, cellulose, gelatin and pectin (Swain \& Bate-Smith, 1962). Tannins are regarded as environmental pollutants. They are toxic to aquatic organisms, inhibit micro-organisms and enzymes involved in the decomposition of organic pollution (Scalbert, 1991) and, in some cases, are recalcitrant to biodegradation (Field \& Lettinga, 1992).

The GenBank accession number for the 16S rRNA gene sequence of strain B7 is AF323911.
Aerobic degradation of tannins has been widely studied. Soil fungi belonging to the genera Aspergillus and Penicillium, yeasts of the genus Pichia and bacteria of the genera Klebsiella, Bacillus, Corynebacterium and Achromobacter are the most frequently observed degraders of hydrolysable tannins. The interest in anaerobic degradation of hydrolysable tannins has resulted from an increase in the application of anaerobic systems for treatment of tannin-containing wastewaters (Field \& Lettinga, 1992).

A previous study of a continuous anaerobic digester fed with shea cake showed high tannin-removal rates and production of organic acids and methane (Ouattara, 1994). Isolation and characterization are reported of a strain of Streptococcus gallolyticus capable of hydrolysing tannic acid and decarboxyl- 
ating gallic acid to pyrogallol from the same digester. Both the novel isolate and the type strain, $S$. gallolyticus ACM $3611^{\mathrm{T}}$, decarboxylated protocatechuic acid to catechol and some $p$-hydroxycinnamic acid derivatives to their corresponding 4-vinyl derivatives. It is proposed to emend the description of $S$. gallolyticus to include these newly described traits.

\section{METHODS}

Source of strains. Strain B7 was isolated from a continuous methanogenic digester located in Burkina Faso. This digester $\left(201,30^{\circ} \mathrm{C}\right)$ was initially inoculated with anaerobic sludge from the pit of a slaughterhouse and fed for 6 months with shea cake. Streptococcus bovis DSM 20480 ${ }^{\mathrm{T}}$ was obtained from the Deutsche Sammlung von Mikroorganismen und Zellkulturen (DSMZ). S. gallolyticus ACM $3611^{\mathrm{T}}$ was obtained from the Australian Collection of Microorganisms. S. gallolyticus CIP 107089, S. gallolyticus CIP 107090 and S. gallolyticus CIP 107091 were obtained from the Collection of the Pasteur Institute.

Culture media. The anaerobic techniques of Hungate (Hungate, 1969; Macy et al., 1972; Miller \& Wolin, 1974) were used throughout this work. The basal medium contained $\left(1^{-1}\right): 0.4 \mathrm{~g} \mathrm{NH}_{4} \mathrm{Cl}, 0.5 \mathrm{~g} \mathrm{KH}_{2} \mathrm{PO}_{4}, 0.4 \mathrm{~g} \mathrm{NaCl}, 0.33 \mathrm{~g}$ $\mathrm{MgCl}_{2} .6 \mathrm{H}_{2} \mathrm{O}, 0.05 \mathrm{~g} \mathrm{CaCl}_{2} .2 \mathrm{H}_{2} \mathrm{O}, 0 \cdot 25 \mathrm{~g}$ cysteine hydrochloride, $2 \mathrm{~g}$ yeast extract (Difco), $1 \mathrm{ml}$ trace-element mineral solution (Widdel \& Pfennig, 1981) and $1 \mathrm{mg}$ resazurin. The $\mathrm{pH}$ was adjusted to 7 with $10 \mathrm{M} \mathrm{KOH}$. The medium was then boiled under a stream of $\mathrm{O}_{2}$-free $\mathrm{N}_{2}$ gas and cooled to room temperature. Aliquots of $5 \mathrm{ml}$ were dispensed into Hungate tubes, degassed under $\mathrm{N}_{2} / \mathrm{CO}_{2}(80: 20 \%, \mathrm{v} / \mathrm{v})$ and subsequently sterilized by autoclaving at $110^{\circ} \mathrm{C}$ for $45 \mathrm{~min}$. Prior to inoculation, $0.05 \mathrm{ml} 10 \%$ (w/v) $\mathrm{NaHCO}_{3}$ and $0.05 \mathrm{ml} 5 \%(\mathrm{w} / \mathrm{v}) \mathrm{Na}_{2} \mathrm{~S} .9 \mathrm{H}_{2} \mathrm{O}$ were injected from sterile stock solutions. Substrates were injected from concentrated anaerobic sterile stock solutions to obtain the desired final concentration.

Strain B7 and the four strains of S. gallolyticus were routinely grown on basal medium containing $5 \mathrm{mM}$ glucose. The type strain of $S$. bovis was grown aerobically at $37^{\circ} \mathrm{C}$ using a medium containing $\left(1^{-1}\right): 10 \mathrm{~g}$ casein peptone-tryptic digest, $5 \mathrm{~g}$ yeast extract, $5 \mathrm{~g}$ glucose and $5 \mathrm{~g} \mathrm{NaCl}$. The $\mathrm{pH}$ was adjusted to 7·2-7.4 with $10 \mathrm{M} \mathrm{KOH}$.

Enrichment and isolation procedure. The digester wastewater sample $(0.5 \mathrm{ml})$ was inoculated into $5 \mathrm{ml}$ basal medium containing $1 \mathrm{~g}$ tannic acid $1^{-1}$ (Aldrich) and incubated at $37^{\circ} \mathrm{C}$. The enrichment culture was subcultured several times under the same conditions prior to isolation. For isolation purposes, the culture was serially diluted tenfold and single well-isolated colonies that developed in roll tubes (basal medium containing $1 \mathrm{~g}$ tannic acid $1^{-1}$ and $1.6 \%$ agar) were picked and serially diluted in fresh media. This procedure was repeated until only one colony type was observed. Purity was checked by microscopic examination of cultures grown in basal medium amended with $10 \mathrm{mM}$ glucose and $0.2 \%$ Biotrypcase (Difco). The isolate was maintained in basal medium containing $1 \mathrm{~g}$ tannic acid $1^{-1}$.

Morphology and sporulation test. Light and electron microscopy were performed as described by Fardeau et al. (1997). For testing heat resistance, cells grown in basal medium containing glucose were exposed to 80, 90 and $100{ }^{\circ} \mathrm{C}$ for $10 \mathrm{~min}$. The cultures were cooled quickly to ambient temperature and inoculated into fresh glucosecontaining medium and growth was recorded after $24 \mathrm{~h}$ incubation at $37^{\circ} \mathrm{C}$. Conditions for sporulation that were tested included growth in the presence of glucose or tannic acid and without added carbon sources.

Growth parameters. For all experiments, basal medium containing $0 \cdot 2 \%$ yeast extract and $10 \mathrm{mM}$ glucose was used. The $\mathrm{pH}$ of the pre-reduced anaerobic medium was adjusted with $5 \% \mathrm{NaHCO}_{3}, 5 \% \mathrm{Na}_{2} \mathrm{CO}_{3}$ or $0 \cdot 1 \mathrm{M} \mathrm{HCl}$ to obtain a $\mathrm{pH}$ range between $5 \cdot 0$ and $9 \cdot 5$. Different amounts of $\mathrm{NaCl}$ were weighed directly in Hungate tubes prior to dispensing $5 \mathrm{ml}$ medium to obtain the desired $\mathrm{NaCl}$ concentration (range $0-50 \mathrm{~g}^{-1}$ ). The temperature range for growth was determined between 10 and $50^{\circ} \mathrm{C}\left(5^{\circ} \mathrm{C}\right.$ intervals $)$.

Electron acceptors. Sulfate, thiosulfate, sulfite, fumarate (all at $20 \mathrm{mM})$ and elemental sulfur $(2 \%, \mathrm{w} / \mathrm{v})$ were tested as electron acceptors in basal medium containing $10 \mathrm{mM}$ glucose.

Substrate utilization. Experiments were performed in duplicate with an inoculum subcultured at least once under the same test conditions. The substrates tested for utilization were injected from pre-sterilized and concentrated stock solutions into Hungate tubes that contained $5 \mathrm{ml}$ presterilized basal medium. The following substrates were used: $20 \mathrm{mM}$ carbohydrates (arabitol, cellobiose, fructose, galactose, glucose, lactose, maltose, mannitol, melibiose, melezitose, myo-inositol, raffinose, ribose, sorbitol, sorbose, trehalose and xylose); $20 \mathrm{mM}$ organic acids (acetate, adipate, butyrate, citrate, crotonate, formate, fumarate, isobutyrate, lactate, malate, propionate, succinate and valerate); $20 \mathrm{mM}$ alcohols (butanol, ethanol, glycerol, isobutanol, 2-propanol, methanol and 1-propanol); $10 \mathrm{~g}$ peptides $1^{-1}$ [Biotrypcase (Difco), Casamino acids (Sigma), gelatin (Sigma), peptone (Difco) and yeast extract (Difco)]; $20 \mathrm{mM}$ phenylalanine; and $5 \mathrm{mM}$ aromatic compounds. Concentrated stock solutions were prepared, neutralized if necessary, rendered anaerobic by gassing with $\mathrm{O}_{2}$-free $\mathrm{N}_{2}$ and sterilized by filtration (pore size $0.2 \mu \mathrm{m}$; Millipore). Aromatic compounds were tested with or without $5 \mathrm{mM}$ glucose. Autotrophic growth was tested using $\mathrm{H}_{2} / \mathrm{CO}_{2}(20$ : $80 \%, \mathrm{v} / \mathrm{v}$ ) at a final pressure of 2 bar. An increase in $\mathrm{OD}_{580}$ in tubes containing added substrates, compared with control tubes lacking substrate, was considered as positive growth.

Analytical techniques. Bacterial growth was monitored by measuring the $\mathrm{OD}_{580}$ directly from anaerobic Hungate tubes inserted into the cuvette holder of a spectrophotometer (Shimadzu UV 160A). Aromatic compounds, carbohydrates, volatile fatty acids and alcohols were measured by HPLC as described by Mechichi et al. (1999). $\mathrm{H}_{2}$ and $\mathrm{CO}_{2}$ were measured as described by Fardeau et al. (1993).

Determination of the $\mathbf{G}+\mathbf{C}$ content and DNA-DNA hybridization. The DNA G $+\mathrm{C}$ content was determined by the DSMZ. DNA was isolated and purified by chromatography on hydroxyapatite (Cashion et al., 1977) and the $\mathrm{G}+\mathrm{C}$ content was determined by HPLC as described by Mesbah et al. (1989). Non-methylated lambda DNA (Sigma) was used as the standard. DNA-DNA hybridization was performed at the DSMZ as described by De Ley et al. (1970), with the modifications described by Escara \& Hutton (1980) and Huß et al. (1983), using a Gilford System model 2600 equipped with a Gilford model 2527-R thermoprogrammer and plotter. Renaturation rates were computed with the TRANSFER.BAS program of Jahnke \& Bahnweg (1986) and Jahnke (1992).

DNA extraction and amplification of the 16S rRNA gene. DNA was extracted from the isolate as described by Woo et al. (1997). Amplification and sequencing of the 16S rRNA 
was done as described by Redburn \& Patel (1993) and Andrews \& Patel (1996). The sequence data that were generated were aligned to an almost full-length consensus 16S rRNA gene sequence, assembled and checked manually for accuracy using the alignment editor ae2 (Maidak et al., 2000). These were compared with other sequences in the GenBank database using BLAST (Altschul et al., 1997) and in the Ribosomal Database Project, version 8.0, using SIMILARITY_RANK and SUGGEST_TREE (Maidak et al., 2000). Pairwise evolutionary distances based on 1235 unambiguous nucleotides were computed using the programs DNADIST (Jukes \& Cantor, 1969) and NEIGHBOR that form part of the PHYLIP suite of programs (Felsenstein, 1993). TREECON was used extensively for bootstrap analysis (Van de Peer \& De Wachter, 1994).

\section{RESULTS AND DISCUSSION}

\section{Enrichment and isolation}

Enrichment cultures developed in medium containing $1 \mathrm{~g}$ tannic acid $\mathbf{1}^{-1}$ within 3 weeks of incubation at $37^{\circ} \mathrm{C}$, as shown by growth and pyrogallol production. After several transfers in the liquid medium, the enrichment developed a stable microbial population that degraded tannic acid. Several isolates were obtained using the roll-tube method (Hungate, 1969) and one of these cultures, designated strain B7, was studied further.

\section{Morphology and physiology}

Cells of strain B7 were non-motile cocci $(<2 \mu \mathrm{m}$ in diameter) that occurred in pairs or short chains and stained Gram-positive. Spores were not observed and cells did not survive heat treatment of $10 \mathrm{~min}$ at $80^{\circ} \mathrm{C}$, indicating an absence of heat-resistant cells. Strain B7 was a facultatively anaerobic bacterium. The temperature range for growth was $15-48^{\circ} \mathrm{C}$, with optimal growth at $40^{\circ} \mathrm{C}$. No growth occurred at 10 or $50{ }^{\circ} \mathrm{C}$. The $\mathrm{pH}$ range for growth was $\mathrm{pH} 5 \cdot 0-9 \cdot 0$, with an optimum at $\mathrm{pH} 7 \cdot 0$. The $\mathrm{NaCl}$ concentration range for growth was $0-40 \mathrm{~g} \mathrm{l}^{-1}$. Yeast extract stimulated growth, but was not required. Strain B7 fermented a wide range of carbohydrates including cellobiose, fructose, galactose, glucose, lactose, maltose, mannitol, melibiose, raffinose and trehalose, producing predominantly lactate and minor amounts of acetate, formate and ethanol, but no gas. Malate and yeast extract were fermented into lactate. Isolate B7 did not utilize arabitol, melezitose, myo-inositol, ribose, sorbitol, sorbose or xylose, any of the organic acids tested, any of the alcohols tested, peptides, including Biotrypcase, Casamino acids, gelatin or peptone, phenylalanine or $\mathrm{H}_{2} / \mathrm{CO}_{2}$. Sulfate, thiosulfate, sulfite, elemental sulfur and fumarate could not be used as electron acceptors.

\section{G + C content, 16S rRNA gene sequence analysis and DNA-DNA relatedness}

The $\mathrm{G}+\mathrm{C}$ content of strain $\mathrm{B} 7$ was $40 \cdot 4 \pm 0 \cdot 3 \mathrm{~mol} \%$, as determined by HPLC. An almost complete $16 \mathrm{~S}$ rRNA gene sequence was obtained for strain B7,

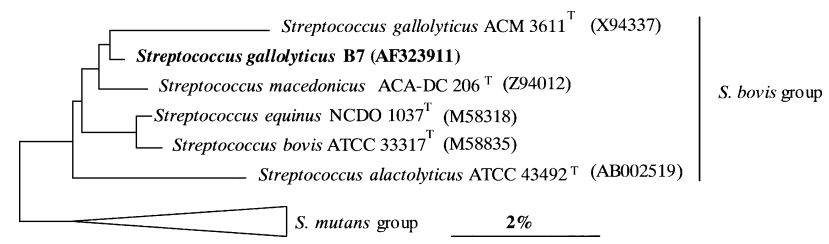

Fig. 1. Phylogenetic position of strain $B 7$ within the radiation of the $S$. bovis group. The $S$. bovis group is represented by S. gallolyticus, S. macedonicus, S. equinus, S. bovis and $S$. alactolyticus. The outgroup is represented by members of the Streptococcus mutans group, which includes $S$. mutans (AJ243965) and Streptococcus ratti (X58304). For phylogeny, 1235 unambiguous nucleotides were included in the analysis. GenBank accession numbers are provided in parentheses.

consisting of $1535 \mathrm{nt}$. Phylogenetic analysis revealed that strain B7 was closely associated with members of the genus Streptococcus (Hardie, 1986) and, in particular, with $S$. gallolyticus ACM $3611^{\mathrm{T}}$ (similarity of $98 \%$ ), S. bovis DSM 20480 ${ }^{\mathrm{T}}$, Streptococcus equinus NCDO $1037^{\mathrm{T}}$, Streptococcus alactolyticus ATCC $43492^{\mathrm{T}}$, Streptococcus macedonicus ACA-DC $206^{\mathrm{T}}$ and Streptococcus caprinus ACM 3970 (a synonym of $S$. gallolyticus; Sly et al., 1997), with a mean similarity of $98 \%$ (Fig. 1). S. gallolyticus, S. bovis, S. equinus, $S$. alactolyticus, $S$. macedonicus and $S$. caprinus form a cohesive rRNA cluster within the genus Streptococcus that is referred to as the $S$. bovis cluster (Farrow et al., 1984). DNA hybridization studies showed that $S$. gallolyticus, S. bovis, S. equinus, S. alactolyticus and $S$. macedonicus are distinct genospecies (Sly et al., 1997; Tsakalidou et al., 1998; Kawamura et al., 1998). The level of DNA-DNA relatedness was $29 \%$ between strain B7 and S. bovis DSM $20480^{\mathrm{T}}$ and $86 \%$ between strain B7 and S. gallolyticus ACM $3611^{\mathrm{T}}$. According to phylogenetic analysis, strain B7 is a member of the genus Streptococcus and, in particular, the $S$. bovis group, which forms a cohesive rRNA cluster, with a mean similarity of greater than $97 \%$. The level of DNA relatedness between strain $\mathrm{B} 7$ and $S$. gallolyticus ACM $3611^{\mathrm{T}}(86 \%)$ indicates that it should be regarded as a strain of S. gallolyticus. Phenotypically, strain B7 ferments mannitol, hydrolyses tannic acid to release gallic acid and decarboxylates gallic acid to pyrogallol, traits it possesses in common with $S$. gallolyticus isolates (Sly et al., 1997; Brooker et al., 1994; Osawa \& Sly, 1992; Osawa et al., 1993), but not with other members of the $S$. bovis group.

S. gallolyticus has so far been isolated from diverse habitats including the faeces of koalas, kangaroos, brushtail, possums, ringtail possums, cows, horses, pigs, dogs and guinea pigs, as well as animals with bovine mastitis, human clinical sources and the sheep rumen (Osawa et al., 1995; Sly et al., 1997). Nelson et al. (1998) reported that tolerance of and/or degradation of tannins by rumen bacteria was widespread. The isolation of strain B7 from an anaerobic digester fed with shea cake extends the known habitat for $S$. gallolyticus. The isolation of B7 from such an en- 
Table 1. Metabolism of aromatic compounds by strain B7 and S. gallolyticus ACM $3611^{\top}$

Bacteria were grown in basal medium containing $0 \cdot 2 \%$ yeast extract; aromatic compounds were used at $5 \mathrm{mM}$, with or without $5 \mathrm{mM}$ glucose. Results were recorded after 2 days anaerobic incubation at $37^{\circ} \mathrm{C}$. For strain $\mathrm{B} 7$, the $\Delta \mathrm{OD}_{580}$ (difference between $\mathrm{OD}_{580}$ after incubation at $37^{\circ} \mathrm{C}$ and $\mathrm{OD}_{580}$ prior to incubation) of the culture was $0 \cdot 10-0 \cdot 13$ without added glucose and 0.54-0.66 with added glucose. For $S$. gallolyticus ACM $3611^{\mathrm{T}}$, the $\Delta \mathrm{OD}_{580}$ of the culture was $0 \cdot 11-0 \cdot 13$ without added glucose and $0 \cdot 57-0 \cdot 68$ with added glucose.

\begin{tabular}{|c|c|c|c|c|c|}
\hline \multirow[t]{3}{*}{ Aromatic acid metabolized } & \multirow[t]{3}{*}{ Compound produced } & \multicolumn{4}{|c|}{ Amount of product (mM) } \\
\hline & & \multicolumn{2}{|c|}{ Without glucose } & \multicolumn{2}{|c|}{ With glucose } \\
\hline & & B7 & $\operatorname{ACM} 3611^{\mathrm{T}}$ & B7 & ACM $3611^{\mathrm{T}}$ \\
\hline Tannic acid & Pyrogallol & $3 \cdot 4$ & $3 \cdot 1$ & $3 \cdot 3$ & $3 \cdot 4$ \\
\hline Gallic acid & Pyrogallol & $3 \cdot 6$ & $2 \cdot 9$ & $4 \cdot 8$ & $4 \cdot 1$ \\
\hline Protocatechuic acid & Catechol & $1 \cdot 8$ & $2 \cdot 2$ & $4 \cdot 9$ & $4 \cdot 8$ \\
\hline$p$-Coumaric acid & Vinylphenol & $4 \cdot 5$ & $4 \cdot 8$ & $4 \cdot 8$ & $4 \cdot 7$ \\
\hline Caffeic acid & Vinylcatechol & $3 \cdot 0$ & $2 \cdot 8$ & $4 \cdot 8$ & $4 \cdot 8$ \\
\hline Ferulic acid & Vinylguaiacol & $2 \cdot 9$ & $2 \cdot 3$ & $4 \cdot 2$ & $4 \cdot 3$ \\
\hline
\end{tabular}

vironment after enrichment on tannic acid is not surprising, as the digester was rich in tannins and aromatic compounds and had been inoculated with anaerobic sludge from the pit of a slaughterhouse.

\section{Metabolism of aromatic compounds}

Strain B7 hydrolysed tannic acid (hydrolysable tannin) at $1 \mathrm{~g} \mathrm{l}^{-1}$ to release gallic acid, which was subsequently decarboxylated to pyrogallol. Glucose supplementation enhanced cell growth and markedly accelerated this conversion (Table 1). Tannin concentrations greater than $17 \mathrm{~g} \mathrm{l}^{-1}$ inhibited growth. Gallic acid, which is a monomer of tannic acid, was decarboxylated to pyrogallol, with or without added glucose (Table 1). Pyrogallol was the end product and the aromatic ring was not degraded after 1 month of incubation.

The following benzoic acid derivatives tested in the presence or absence of glucose were not metabolized: benzoate, hydroxylated benzoic acids (4-hydroxybenzoate, 3,5-, 2,4- and 2,6-dihydroxybenzoates and 2,4,6-trihydroxybenzoate), methoxylated benzoic acids (2,4-, 2,6-, 3,4- and 3,5-dimethoxybenzoates and 3,4,5-trimethoxybenzoate), mixed hydroxylated/ methoxylated benzoic acids (4-hydroxy-3-methoxybenzoate, 3-hydroxy-4-methoxybenzoate and 4hydroxy-3,5-dimethoxybenzoate) and 3,4-dimethylbenzoate. However, protocatechuic acid (3,4dihydroxybenzoate) was decarboxylated to catechol. Again, the addition of glucose accelerated this conversion (Table 1).

Of a number of cinnamic compounds tested, namely cinnamic, $o-, m$ - and $p$-coumaric, caffeic, ferulic, isoferulic and 3,4,5-trimethoxycinnamic acids, with or without added glucose, only $p$-coumaric, caffeic and ferulic acids were metabolized to their corresponding 4-vinyl (styrene) derivatives, respectively 4- vinylphenol (4-hydroxystyrene), 4-vinylcatechol (3,4dihydroxystyrene) and 4-vinylguaiacol (4-hydroxy-3methoxystyrene) (Table 1). The mechanism involved decarboxylation of the carboxyl group in the unsaturated $\mathrm{C}_{3}$-aliphatic side chain. Supplementation with glucose increased the conversion yield.

Strain B7 did not decarboxylate phenylpropionic acids (hydrocinnamate and hydrocaffeate) or phenylacetic acids (phenylacetate, $p$-hydroxyphenylacetate, 2,5and 3,4-dihydroxyphenylacetates, p-methoxyphenylacetate and 3,4-dimethoxyphenylacetate), with or without added glucose, indicating a specific selection. In addition, pyrogallol and phloroglucinol were not metabolized.

The ratio of pyrogallol, catechol and 4-vinyl derivatives to their corresponding gallic, protocatechuic and 4-hydroxycinnamic acids in the medium increased during the course of the experiment until the utilization of the substrate was complete. Adding glucose increased cellular yield and markedly accelerated these conversions. With all aromatic compounds tested, and even after 1 month incubation, no ring cleavage was observed.

The metabolism of aromatic compounds by the type strain, S. gallolyticus ACM 3611 ${ }^{\mathrm{T}}$, and $S$. gallolyticus CIP 107089, S. gallolyticus CIP 107090 and S. gallolyticus CIP 107091 was similar to that observed with strain B7. Of all the aromatic compounds tested above, these four strains of $S$. gallolyticus decarboxylated only gallic acid to pyrogallol, protocatechuic acid to catechol, p-coumaric acid to 4-vinylphenol, caffeic acid to 4-vinylcatechol and ferulic acid to 4vinylguaiacol. Supplementation with glucose increased the conversion yield. The aromatic ring was not degraded, even after 1 month of incubation under anaerobic conditions. 
In addition to hydrolysis of tannic acid and decarboxylation of gallic acid to pyrogallol, the type strain of $S$. gallolyticus, strain B7 and three other strains of $S$. gallolyticus decarboxylated protocatechuic acid to catechol and three hydroxycinnamic acids to their corresponding styrene derivatives. These characteristics have not so far been reported for $S$. gallolyticus. From these studies, it can be deduced that (i) both hydroxyl groups in the para and meta positions on the aromatic ring of benzoic acid derivatives were essential for decarboxylation and (ii) cinnamate derivates were metabolized by decarboxylation of the carboxyl group in the unsaturated $\mathrm{C}_{3}$-aliphatic side chain when the ring was substituted with a parahydroxyl group. In no case was the aromatic ring cleaved. Studies have also shown that the addition of glucose increased cellular yield and conversion yield, but not the range of metabolizable substrates. The physiological significance of these decarboxylations is not known. One possible effect may be to prevent acid accumulation in the medium; alternatively, the microorganisms may conserve energy (as membrane potential) from the decarboxylation or the antiport of a negatively charged substrate into the cell and a neutral product out of the cell (Heider \& Fuchs, 1997).

It is proposed that the description of $S$. gallolyticus be emended to include the novel characteristics described in this report.

\section{Emended description of Streptococcus gallolyticus (Osawa et al. 1995)}

Streptococcus gallolyticus (gal.lo.ly'ti.cus. N.L. n. gallatum gallate; N.L. adj. lyticus able to loosen; N.L. adj. gallolyticus gallate-digesting).

Colonies on blood agar or brain/heart infusion agar are circular, smooth and entire. Non-pigmented. Nonhaemolytic. Coccoid cells mostly in pairs or short chains. Non-motile. Facultatively anaerobic with some strains requiring $\mathrm{CO}_{2}$. Catalase-negative. Growth between 10 and $45{ }^{\circ} \mathrm{C}$; optimum $37-40^{\circ} \mathrm{C}$. No growth at $50{ }^{\circ} \mathrm{C}$. Chemo-organotrophic. Majority of strains have tannase activity. Metabolism fermentative. Acid produced from a wide range of carbohydrates including cellobiose, fructose, galactose, glucose, lactose, maltose, melibiose and trehalose. Majority of the strains ferment raffinose and mannitol. Acid is not produced from ribose or sorbitol. Majority of strains hydrolyse aesculin. Hippurate is not hydrolysed. Voges-Proskauer-positive. Leucine arylamidase-positive. Majority of strains are $\alpha$-galactosidase-positive. Arginine dihydrolase- and alkaline phosphatase-negative. Decarboxylates gallic acid to pyrogallol, protocatechuic acid to catechol, $p$-coumaric acid to 4vinylphenol, caffeic acid to 4-vinylcatechol and ferulic acid to 4-vinylguaiacol, with or without added glucose. Supplementation with glucose markedly accelerates these conversions. Benzoate, 4-hydroxybenzoate, 3,5-, 2,4- and 2,6-dihydroxybenzoates, 2,4,6-trihydroxybenzoate, 2,4-, 2,6-, 3,4- and 3,5-dimethoxybenzoates, 3,4,5-trimethoxybenzoate, 4-hydroxy-3-methoxybenzoate, 3-hydroxy-4-methoxybenzoate, 4-hydroxy3,5-dimethoxybenzoate, 3,4-dimethylbenzoate, pyrogallol, phloroglucinol, cinnamate, $o-$ and $m$ hydroxycinnamates, 3-hydroxy-4-methoxycinnamate, 3,4,5-trimethoxycinnamate, 3-phenylpropionate, 3,4dihydroxyphenylpropionate, phenylacetate, $p$ hydroxyphenylacetate, 2,5- and 3,4-dihydroxyphenylacetates, $p$-methoxyphenylacetate and 3,4-dimethoxyphenylacetate are not metabolized, with or without addition of glucose. The genomic DNA G $+\mathrm{C}$ content is $37-40 \mathrm{~mol} \%$. Isolated from alimentary tracts of various animals, human clinical cases, including septicaemia and endocarditis, and an anaerobic digester fed with shea cake, previously inoculated with anaerobic sludge from the pit of a slaughterhouse. The type strain is ACM 3611 ${ }^{\mathrm{T}}$; reference strain B7 (= DSM $13808=$ CIP 106781).

\section{ACKNOWLEDGEMENTS}

Financial assistance to M. C. from the Tunisian Minister for Superior Teaching and the French Research Institute for Development (IRD) and to B.K.C.P. from the Australian Research Council is gratefully acknowledged. Many thanks to Pierre A. Roger for revising the manuscript.

\section{REFERENCES}

Altschul, S. F., Madden, T. L., Schaffer, A. A., Zhang, J., Zhang, Z., Miller, W. \& Lipman, D. J. (1997). Gapped BLAST and PSI-BLAST: a new generation of protein database search programs. Nucleic Acids Res $\mathbf{2 5}$, 3389-3402.

Andrews, K. T. \& Patel, B. K. C. (1996). Fervidobacterium gondwanense sp. nov., a new thermophilic anaerobic bacterium isolated from nonvolcanically heated geothermal waters of the Great Artesian Basin of Australia. Int J Syst Bacteriol 46, 265-269.

Brooker, J. D., O’Donovan, L. A., Skene, I., Clarke, K., Blackall, L. \& Muslera, P. (1994). Streptococcus caprinus sp. nov., a tannin-resistant ruminal bacterium from feral goats. Lett Appl Microbiol 18, 313-318.

Cashion, P., Holder-Franklin, M. A., McCully, J. \& Franklin, M. (1977). A rapid method for base ratio determination of bacterial DNA. Anal Biochem 81, 461-466.

De Ley, P., Cattoir, H. \& Reynaerts, A. (1970). The quantitative measurement of DNA hybridization from renaturation rates. Eur $J$ Biochem 12, 133-142.

Escara, J. F. \& Hutton, J. R. (1980). Thermal stability and renaturation of DNA in dimethyl sulfoxide solutions: acceleration of the renaturation rate. Biopolymers 19, 1315-1327.

Fardeau, M.-L., Cayol, J.-L., Magot, M. \& Ollivier, B. (1993). $\mathrm{H}_{2}$ oxidation in the presence of thiosulfate, by a Thermoanaerobacter strain isolated from an oil-producing well. FEMS Microbiol Lett 113, 327-332.

Fardeau, M.-L., Ollivier, B., Patel, B. K. C., Magot, M., Thomas, P., Rimbault, A., Rocchiccioli, F. \& Garcia, J.-L. (1997). Thermotoga hypogea sp. nov., a xylanolytic, thermophilic bacterium from an oilproducing well. Int J Syst Bacteriol 47, 1013-1019.

Farrow, J. A. E., Kruze, J., Phillips, B. A., Bramley, A. J. \& Collins, M. D. (1984). Taxonomic studies on Streptococcus bovis and Streptococcus equinus: description of Streptococcus alactolyticus sp. nov. and Streptococcus saccharolyticus sp. nov. Syst Appl Microbiol 5, 467-482.

Felsenstein, J. (1993). PHYLIP (phylogenetic inference package), version 3.51c. Department of Genetics, University of Washington, Seattle, WA, USA.

Field, J. A. \& Lettinga, G. (1992). Biodegradation of tannins. Metal Ions Biol Syst 28, 61-97. 
Hardie, J. M. (1986). Streptococcus bovis Orla-Jensen 1919, 137; emend mut. char. Sherman and Wing 1937, 57 $7^{\mathrm{AL}}$. In Bergey's Manual of Systematic Bacteriology, vol. 2, p. 1069. Edited by P. H. A. Sneath, N. S. Mair, M. E. Sharpe \& J. G. Holt. Baltimore: Williams \& Wilkins. Heider, J. \& Fuchs, G. (1997). Microbial anaerobic aromatic metabolism. Anaerobe 3, 1-22.

Hungate, R. E. (1969). A roll-tube method for the cultivation of strict anaerobes. Methods Microbiol 136, 194-198.

Huß, V. A. R., Festl, H. \& Schleifer, K. H. (1983). Studies on the spectrometric determination of DNA hybridization from renaturation rates. Syst Appl Microbiol 4, 184-192.

Jahnke, K.-D. (1992). Basic computer program for evaluation of spectroscopic DNA renaturation data from GILFORD System 2600 spectrometer on a PC/XT/AT type personal computer. J Microbiol Methods 15, 61-73.

Jahnke, K.-D. \& Bahnweg, G. (1986). Assessing natural relationships in the basidiomycetes by DNA analysis. Trans Brit Mycol Soc 87, 175-191.

Jukes, T. H. \& Cantor, C. R. (1969). Evolution of protein molecules. In Mammalian Protein Metabolism, vol. 3, pp. 21-132. Edited by H. N. Munro. New York: Academic Press.

Kawamura, Y., Hou, X.-G., Todome, Y., Sultana, F., Hirose, K., Shu, S.-E., Ezaki, T. \& Ohkuni, H. (1998). Streptococcus peroris sp. nov. and Streptococcus infantis sp. nov., new members of the Streptococcus mitis group, isolated from human clinical specimens. Int J Syst Bacteriol 48, 921-927.

Macy, J. M., Snellen, J. E. \& Hungate, R. E. (1972). Use of syringe methods for anaerobiosis. Am J Clin Nutr 25, 1318-1323.

Maidak, B. L., Cole, J. R., Lilburn, T. G. \& 9 other authors (2000). The RDP (Ribosomal Database Project) continues. Nucleic Acids Res 28, 173-174.

Mechichi, T., Labat, M., Patel, B. K. C., Woo, T. H. S., Thomas, P. \& Garcia, J.-L. (1999). Clostridium methoxybenzovorans sp. nov., a new aromatic $o$-demethylating homoacetogen from an olive mill wastewater treatment digester. Int J Syst Bacteriol 49, 1201-1209.

Mesbah, M., Premachandran, U. \& Whitman, W. B. (1989). Precise measurement of the $\mathrm{G}+\mathrm{C}$ content of deoxyribonucleic acid by highperformance liquid chromatography. Int J Syst Bacteriol 39, 159-167.

Miller, T. L. \& Wolin, M. J. (1974). A serum bottle modification of the Hungate technique for cultivating obligate anaerobes. Appl Microbiol 27, 985-987.
Nelson, K. E., Thonney, M. L., Woolston, T. K., Zinder, S. H. \& Pell, A. N. (1998). Phenotypic and phylogenetic characterization of ruminal tannin-tolerant bacteria. Appl Environ Microbiol 64, 3824-3830.

Osawa, R. \& Sly, L. I. (1992). Occurrence of tannin-protein complex degrading Streptococcus sp. in various animals. Syst Appl Microbiol 15, 144-147.

Osawa, R., Walsh, T. P. \& Cork, S. J. (1993). Metabolism of tanninprotein complex by facultative anaerobic bacteria isolated from koala feces. Biodegradation 4, 91-99.

Osawa, R., Fujisawa, T. \& Sly, L. I. (1995). Streptococcus gallolyticus sp. nov.: gallate degrading organisms formerly assigned to Streptococcus bovis. Syst Appl Microbiol 18, 74-78.

Ouattara, C. A. T. (1994). La biodégradation des sous-produits des industries agro-alimentaires pour la protection de l'environnement: cas des tourteaux de karité des huileries de Bobo-Dioulasso (Burkina Faso). $\mathrm{PhD}$ thesis, Université de Ouagadougou, Burkina Faso.

Redburn, A. C. \& Patel, B. K. C. (1993). Phylogenetic analysis of Desulfotomaculum thermobenzoicum using polymerase chain reactionamplified 16S rRNA-specific DNA. FEMS Microbiol Lett 113, 81-86.

Scalbert, A. (1991). Antimicrobial properties of tannins. Phytochemistry 30, 3875-3883.

Sly, L. I., Cahill, M. M., Osawa, R. \& Fujisawa, T. (1997). The tannindegrading species Streptococcus gallolyticus and Streptococcus caprinus are subjective synonyms. Int J Syst Bacteriol 47, 893-894.

Swain, T. \& Bate-Smith, E. C. (1962). In Comparative Biochemistry, vol. 3A, pp. 755-809. New York: Academic Press.

Tsakalidou, E., Zoidou, E., Pot, B., Wassill, L., Ludwig, W., Devriese, L. A., Kalantzopoulos, G., Schleifer, K. H. \& Kersters, K. (1998). Identification of streptococci from Greek Kasseri cheese and description of Streptococcus macedonicus sp. nov. Int J Syst Bacteriol 48, 519-527.

Van de Peer, Y. \& De Wachter, R. (1994). TREECON for Windows: a software package for the construction and drawing of evolutionary trees for the Microsoft Windows environment. Comput Appl Biosci 10, 569-570.

Widdel, F. \& Pfennig, N. (1981). Studies on dissimilatory sulfatereducing bacteria that decompose fatty acids. I. Isolation of new sulfatereducing bacteria enriched with acetate from saline environments. Description of Desulfobacter postgatei gen. nov., sp. nov. Arch Microbiol 129, 395-400.

Woo, T. H. S., Patel, B. K. C., Smythe, L. D., Norris, M. A., Symonds, M. L. \& Dohnt, M. F. (1997). Identification of pathogenic Leptospira by TaqMan Probe in a LightCycler. Anal Biochem 256, 132-134. 